\title{
妊娠期・授乳期の母親ラット，仔ラットに対する ゲニステインとダイゼイン投与における生体影響の相違
}

東 泉 裕 子*1, 梅 木 美 樹*2, 石 見 佳 子*3, 池上 幸 江*4

${ }^{* 1}$ 聖徳大学人文学部, ${ }^{* 2}$ 大分大学教育福祉科学部, $*^{3}$ 独立行政法人国立健康 - 栄養研究所, * 4 大妻女子大学家政学部

Different Effects of the Soy Isoflavones, Genistein and Daidzein, on Pregnant and Lactating Rats and Their Offspring

Yuko Tousen*1, Miki Umeki ${ }^{* 2}$, Yoshiko Ishimi ${ }^{* 3}$ and Sachie Ikegami*4

${ }^{* 1}$ Department of Human Life and Culture, Seitoku University ;

${ }^{*}$ Faculty of Education and Welfare Science, Oita University ;

${ }^{*}$ National Institute of Health and Nutrition ;

${ }^{*}$ Department of Home Economics, Otsuma Women's University

The objects of the present study were to confirm the safety and compare the effects of the soy isoflavones, genistein and daidzein, on rat dams and their offspring. Sprague-Dawley rats were fed with a control diet or diet containing $0.50 \mathrm{~g} / \mathrm{kg}$ of genistein or daidzein during pregnancy and the lactation period until postnatal day 12 . The body weight of the dams fed with the daidzein diet was significantly suppressed during pregnancy and lactation, and the litter weight of the daidzein group was significantly lower at birth compared to the control group and genistein group. The body weight of the offspring during lactation and after weaning was also significantly suppressed in the daidzein group. On the other hand, the body and wet organ weights, dry weight of the femur and anogenital distance in the offspring were not affected by exposure to genistein or daidzein.

Equol was found in the stomach milk and serum of the suckling pups in the daidzein group. The possibility is suggested that equol might have contributed to the obvious effects observed in the daidzein group.

Jpn. J. Nutr. Diet., 64 (3) $161 \sim 172$ (2006)

Key words : soy isoflavone, genistein, daidzein, equol, transfer

\section{緒言}

大豆イソフラボンは人の健康に有効であることが数多 〈報告されている ${ }^{1)}$ 。その主成分であるゲニステイン， ダイゼインへの関心は近年世界中で高まっている。それ らの物質はエストロゲンレセプター（ER）に対して強 い親和性をもつことから，エストロゲン様の活性をもつ ことが知られている ${ }^{2,3)}$ 。そのため大豆イソフラボンは 乳癌, 前立腺癌, 骨粗鬆症などホルモン依存性疾患のホ ルモン交換療法に有効であり，大豆製品を多く摂取する アジア地域ではそれらの疾病率が低いことが報告されて いる ${ }^{4 \sim 7)}$ 。

一方で，イソフラボンはエストロゲン様作用をもつこ とから内分泌攪乱化学物質としての作用も懸念されてい る。とくにホルモン感受性が強く, 発達の著しい胎児 期・授乳期において，母親を介した仔へのイソフラボン
移行に関しては問題となっている。妊娠動物へのエスト ロゲン投与は, 妊娠時の母親の体重増加量, 飼料摂取量 の低下を起こし, それらの結果として出生数, 出生時体 重の低下など妊娠へ有害な影響を引き起こすことが報告 されている ${ }^{8)}$ 。また大豆を摂取した母親ラットの母乳を 与えられた乳仔ラットでは, その仔の思春期や成長後で の影響が観察されている ${ }^{9)}$

他方, 甲状腺腫と甲状腺機能低下症は，大豆を基にし た乳児用ミルクを摂取した乳児で報告されており ${ }^{10)}$ ，さ らに生まれて間もない時期での大豆摂取もまた自己免疫 甲状腺障害の進行と関係しているとの報告もある ${ }^{11) 。 し ~}$ かし，母親とその乳児の甲状腺へのイソフラボンの影響 を観察した報告は少ない。

また，多くの論文において様々な投与量で，母乳，経 口投与，乳仔への皮下注射などの方法でゲニステインを

キーワード：大豆イソフラボン, ゲニステイン，ダイゼイン，エクオール，移行

（連絡先：東泉裕子 † 271-8555 松戸市岩瀬550 聖德大学人文学部生活文化学科食品衛生学研究室 電話 047-365-1111 FAX 047-363-1401 E-mail tousen@seitoku.ac.jp) 
投与したときの影響が報告されているが12 14)，それら の結果は論文間において一貫していない。さらに，ゲニ ステイン，ダイゼインの影響比較は卵巣摘出モデル動物 を用いて骨代謝について報告されているが15), 妊娠動物 やその仔を用いた生体影響での比較はほとんどされてい ない。

すでに我々は大豆イソフラボン混合物（イソフラボン 含量 $33.3 \%$ ；ゲニステイン $14.9 \%$ ，ダイゼイン $16.4 \%$, グリスチン $2.03 \%$ ）を妊娠ラットに投与した実験におい て，母親ラットでは体重減少と肝臓の肥大を観察してい る(投稿中)。さらに出産数の減少傾向と吸収された胎 仔の増加傾向がみられた。また，母親ラットと乳仔ラッ トにおいて甲状腺ホルモン濃度への影響も観察された。 大豆に含まれるイソフラボンの主成分としてはゲニステ インとダイゼインが知られている。しかし，これらの結 果は純粋なゲニステインを用いた同様の実験では観察さ れなかった（投稿中）。そこで大豆イソフラボン混合物 投与により観察された生体影響は，ダイゼインが原因で ある可能性が考えられる。

ダイゼインの ERへの親和性はゲニステインより低 く，内分泌攪乱作用は低いと考えられてきた。他方，ダ イゼインの代謝産物であるエクオールが ERに対して強 い結合親和力をもつことが近年示唆されている ${ }^{16)}$ 。従っ て, 血清中のエクオール濃度を知ることは, ダイゼイン のエストロゲン様活性による生体影響を明らかにするた めに重要である。しかし, 妊娠中および授乳期間中での 母親ラットの飼料摂取による仔ラットへのダイゼイン,
エクオールの移行を観察した報告は少ない。

本研究は母親ラットとその母親から産まれた仔ラット において，大豆イソフラボンの主成分であるゲニステイ ン，ダイゼインを含む飼料の投与による生体影響の相違 を比較し，それらの安全性を確認することを目的として 実験を行った。

Table 1 Composition of experimental diets ${ }^{1}$

\begin{tabular}{|c|c|c|c|}
\hline & & & / kg diet) \\
\hline Constituent & $\begin{array}{l}\text { Control } \\
\text { diet }\end{array}$ & $\begin{array}{c}\text { Genistein } \\
\text { diet }\end{array}$ & $\begin{array}{c}\text { Daidzein } \\
\text { diet }\end{array}$ \\
\hline Cornstarch & 529.5 & 529.0 & 529.0 \\
\hline Sucrose & 100 & 100 & 100 \\
\hline Casein & 200 & 200 & 200 \\
\hline Corn oil & 70 & 70 & 70 \\
\hline Cellulose & 50 & 50 & 50 \\
\hline Mineral mix & 35 & 35 & 35 \\
\hline Vitamin mix & 10 & 10 & 10 \\
\hline L-Cystine & 3 & 3 & 3 \\
\hline Cholin bitartrate & 2.5 & 2.5 & 2.5 \\
\hline $\begin{array}{l}\text { Tert-butyl } \\
\text { hydroquinone }\end{array}$ & 0.014 & 0.014 & 0.014 \\
\hline Genistein ${ }^{2}$ & - & 0.51 & - \\
\hline Daidzein $^{2}$ & - & - & 0.52 \\
\hline
\end{tabular}

${ }^{1}$ Prepared according to AIN-93G formulation.

${ }^{2}$ Genistein and daidzein (Fujicco Co., Ltd., Kobe) were mixed at a level $0.50 \mathrm{~g} / \mathrm{kg}$ as based on their purities.

Table 2 Body weights of dams fed the control diet or the diet containing genistein or daidzein $0.50 \mathrm{~g} / \mathrm{kg}$ during pregnancy, and the number and body weight of their pups at parturition ${ }^{1}$

\begin{tabular}{|c|c|c|c|}
\hline Group & Control group & Genistein group & Daidzein group \\
\hline \multicolumn{4}{|l|}{ Dams } \\
\hline$n$ & 4 & 4 & 4 \\
\hline $\begin{array}{l}\text { Body weight }(\mathrm{g}) \\
\text { of the pregnancy day } 5\end{array}$ & $250.9 \pm 20.2$ & $249.0 \pm 16.9$ & $248.0 \pm 12.3$ \\
\hline $\begin{array}{l}\text { Body weigh }(\mathrm{g}) \\
\text { of the pregnancy day } 20\end{array}$ & $393.4 \pm 21.6^{\mathrm{a}}$ & $386.9 \pm 23.7^{\mathrm{a}}$ & $312.8 \pm 37.4^{\mathrm{b}}$ \\
\hline \multicolumn{4}{|l|}{ Pups } \\
\hline Total number & $15.0 \pm 1.6$ & $14.8 \pm 1.7$ & $14.0 \pm 2.0$ \\
\hline Male number & $7.8 \pm 2.2$ & $8.2 \pm 1.7$ & $8.0 \pm 1.5$ \\
\hline Female number & $7.3 \pm 2.8$ & $6.5 \pm 3.4$ & $6.0 \pm 2.2$ \\
\hline Total litter weight ${ }^{2}(\mathrm{~g})$ & $97.1 \pm 6.0^{\mathrm{a}}$ & $93.8 \pm 6.8^{\mathrm{a}}$ & $69.1 \pm 10.7^{b}$ \\
\hline Weight/Number (g) & $6.50 \pm 0.36^{\mathrm{a}}$ & $6.39 \pm 0.49^{\mathrm{a}}$ & $4.94 \pm 0.36^{b}$ \\
\hline \multicolumn{2}{|c|}{$\begin{array}{l}{ }^{1} \text { All values are means } \pm \mathrm{SD} \text { (standard deviation). } \\
\text { letter are significantly different at } p<0.05 \text {. }\end{array}$} & \multicolumn{2}{|c|}{${ }^{\mathrm{a}, \mathrm{b}}$ Values not sharing a superscript } \\
\hline
\end{tabular}


方

法

\section{1. 動物}

妊娠 5 日目の Sprague-Dawley系雌ラットを日本クレ ア株式会社（東京）から購入し, プラスチックのケージ に 1 匹ずつ分けて飼育した。離乳後の仔ラットはステン レスのケージで個別に飼育した。ラットは母，仔とも温 度 $\left(23 \pm 1{ }^{\circ} \mathrm{C}\right)$, 湿度 $(50 \pm 5 \%), 12$ 時間の明暗サイク ルで管理された動物室で飼育した。母親ラット，離乳後 の仔ラットともに飼料，蒸留水を自由摂取とした。すべ ての動物は「実験動物の飼養および保管に関する基準」 (昭和 55 年 3 月総理府告示第 6 号) に従い取り扱った。

\section{2. 飼料と成分}

妊娠ラットは購入後よりイソフラボンレベル $0 \mathrm{~g} / \mathrm{kg}$

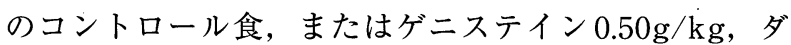
イゼイン $0.50 \mathrm{~g} / \mathrm{kg}$ の飼料を揁取させた。飼料は AIN93Gを基本としたが，大豆油はコーン油に変えた ${ }^{17)}$ 。飼 料組成はTable 1に示した。すべての飼料成分はオリエ ンタル酵母工業株式会社（東京）から，ゲニステイン (純度 $98.04 \%) ，$ ダイゼイン（純度 $96.15 \%$ ）はフジッコ 株式会社（神戸）から購入した。

\section{3. 実験デザイン}

妊娠ラット 12 匹は，コントロール群 (C 群)，ゲニス テイン群 (G群)，ダイゼイン群（D群）の3群に体重が 均一となるように 4 匹ずつ割り当てた。出産日に仔ラッ トの数をそれぞれの親に対し雌 5 匹，雄 5 匹の計 10 匹と し，各群合計 40 匹にそろえた。母親ラットは出産後 12 日目までは各群それぞれの飼料を摂取していたが，13 日目からすべての群の飼料をコントロール食に変えた。 仔ラットは生後 21 日目までは母親ラットと同じケージ で飼育したが，それ以降は飼料（コントロール食）を与 えて個別に飼育した。仔ラットは生後 $4 ， 15 ， 34$ 日目に 母親ラット 1 匹につき雌 1 匹, 雄 1 匹（各群雌 4 匹, 雄 4

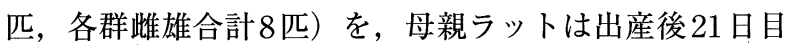
の離乳日に屠殺した。なお，解剖する仔ラットは各群か ら無作為に選定した。解剖時にはそれぞれジエチルエー テル麻酔下で心臟採血を行い，各臟器は摘出後重量を測 定した。心臟より採血した血液は遠心分離 $\left(4{ }^{\circ} \mathrm{C}\right.$, $3,000 \mathrm{rpm}, 20$ 分）した後，分析に使用するまで $-40^{\circ} \mathrm{C}$ で保存した。

\section{4. 測定法}

(1) 仔ラットの anogenital distance

仔ラットの性成熟を評価するために anogenital distance（AGD）を測定し，C群とイソフラボン食群（G 群，D群）とを比較した。AGDとは身体を伸ばしてい ない自然な状態での生殖器官の結節基底から肛門に最も 近い縁部の長さであり，生後4,15日目に測定した。

(2) 大腿骨乾燥重量

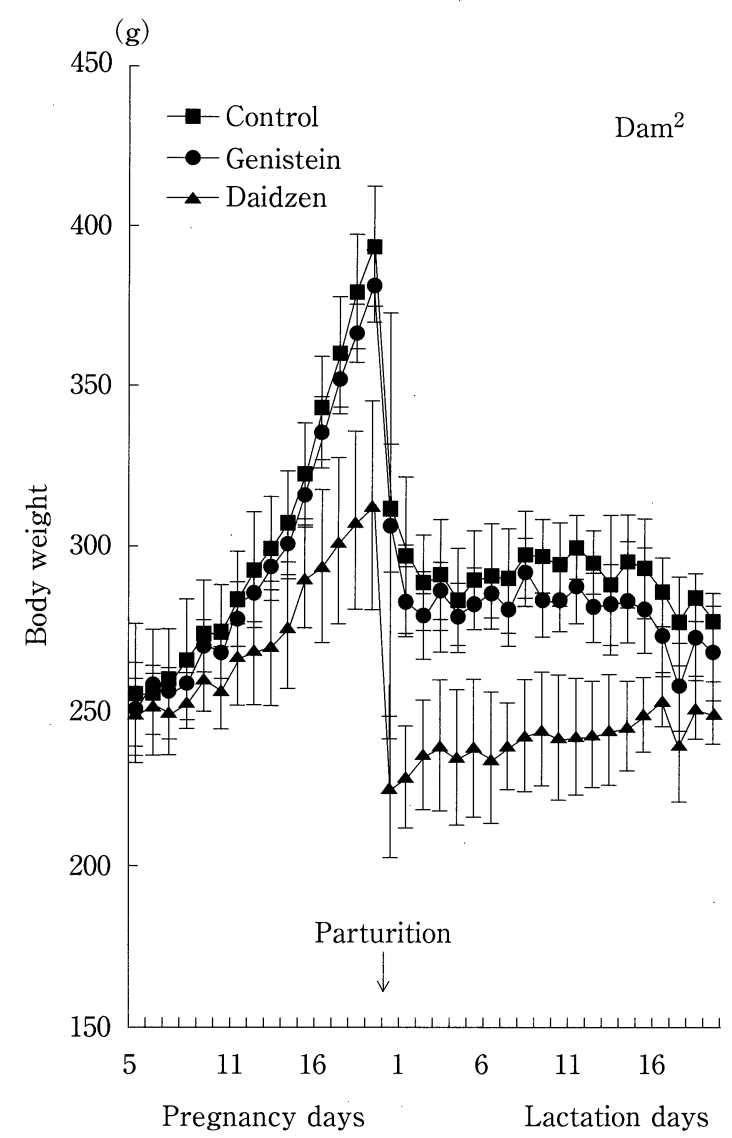

Fig. 1 Changes in body weight of dams fed the control diet or diet containing genistein or daidzein $0.50 \mathrm{~g} / \mathrm{kg}$ during pregnancy and lactation ${ }^{1}$.

${ }^{1}$ The pregnancy period was from pregnancy day 5 to pregnancy day 21 . The lactation period was from lactation day 1 to lactation day 21 after parturition.

${ }^{2}$ Dams in the control group were not exposed to isoflavones and, dams of genistein and daidzein groups were exposed to a $0.50 \mathrm{~g}$ genistein $/ \mathrm{kg}$, and a $0.50 \mathrm{~g}$ daidzein/kg diets during pregnancy and lactation, respectively.

仔ラットは解剖時に左大腿骨を摘出し，付着した筋肉 および軟骨を完全に除去した後，凍結乾燥後に乾燥重量 を求めた。

（3）仔ラットの血清中および胃内容物中のイソフラ ボン分析

血清中のゲニステイン，ダイゼイン，エクオール濃度 はGamache と Acworth らの方法 ${ }^{18)}$ で測定した。仔ラッ トの胃内容物はその $0.5 \mathrm{~g}$ を $0.1 \mathrm{M}$ 酥酸ナトリウム緩衝液 （pH5.0） $1 \mathrm{ml}$ とホモジナイズし，その溶液 $0.5 \mathrm{~g}$ を血清と 同様の方法で処理し分析に用いた。試料溶液は分析セル (検出器 $1: 300 \mathrm{mV}$, 検出器 $2: 600 \mathrm{mV}$ ) (Coulochem III，ESA，MA)，ガードセル (+600mV) のついた電 気化学検出器を備えた高速液体クロマトグラフシステム （HPLC）（Shimazu 10ADシリーズ）に注入した。分離 条件は以下の通りである。 
Table 3 Food intake and food efficiency in dams fed the control diet or diet containing genistein or daidzein $0.50 \mathrm{~g} / \mathrm{kg}$ during pregnancy and lactation ${ }^{1}$

$(\mathrm{g})$

\begin{tabular}{|c|c|c|c|}
\hline Group & $\begin{array}{l}\text { Control group } \\
\quad(n=4)\end{array}$ & $\begin{array}{l}\text { Genistein group } \\
\quad(n=4)\end{array}$ & $\begin{array}{l}\text { Daidzein group } \\
\quad(n=4)\end{array}$ \\
\hline \multicolumn{4}{|l|}{ Food intake $^{2}$} \\
\hline \multicolumn{4}{|l|}{ Pregnancy period } \\
\hline 16 days & $329.7 \pm 25.1^{a}$ & $318.1 \pm 17.0^{a}$ & $221.0 \pm 49.1^{\mathrm{b}}$ \\
\hline \multicolumn{4}{|l|}{ Lactation period } \\
\hline First 12 days & $411.7 \pm 15.9^{\mathrm{a}}$ & $419.9 \pm 23.2^{\mathrm{a}}$ & $325.7 \pm 39.9^{b}$ \\
\hline Last 9 days & $388.9 \pm 18.8^{a}$ & $375.3 \pm 11.4^{\mathrm{a}, \mathrm{b}}$ & $351.1 \pm 18.7^{\mathrm{b}}$ \\
\hline \multicolumn{4}{|c|}{$\begin{array}{l}\text { Food efficiency [Body weight gain }(\mathrm{g}) \text { /food intake }(\mathrm{g})] \\
\text { Pregnancy period }\end{array}$} \\
\hline 16 days & $0.424 \pm 0.030^{\mathrm{a}}$ & $0.434 \pm 0.017^{\mathrm{a}}$ & $0.284 \pm 0.061^{b}$ \\
\hline \multicolumn{3}{|c|}{$\begin{array}{l}{ }^{1} \text { All values are means } \pm \mathrm{SD} \text { (standard deviation). } \\
\text { letter are significantly different at } p<0.05 \text {. }\end{array}$} & aring a superscript \\
\hline
\end{tabular}

Table 4 Organ weights of dams fed the control diet or diet containing genistein or daidzein $0.50 \mathrm{~g} / \mathrm{kg}$ during pregnancy and lactation at day 21 after parturition ${ }^{1}$

\begin{tabular}{lccc} 
& & \multicolumn{2}{c}{$(\mathrm{g} / 100 \mathrm{~g}$ body weight $)$} \\
\hline Group & $\begin{array}{c}\text { Control group } \\
(n=4)\end{array}$ & $\begin{array}{c}\text { Genistein group } \\
(n=4)\end{array}$ & $\begin{array}{c}\text { Daidzein group } \\
(n=4)\end{array}$ \\
\hline Liver & $4.51 \pm 0.59^{\mathrm{a}, \mathrm{b}}$ & $4.27 \pm 0.22^{\mathrm{a}}$ & $5.05 \pm 0.25^{\mathrm{b}}$ \\
Kidney & $0.684 \pm 0.024$ & $0.690 \pm 0.051$ & $0.674 \pm 0.033$ \\
Spleen & $0.205 \pm 0.018$ & $0.195 \pm 0.011$ & $0.212 \pm 0.028$ \\
Thymus & $0.064 \pm 0.010$ & $0.056 \pm 0.011$ & $0.046 \pm 0.017$ \\
Perirenal fat & $0.322 \pm 0.144$ & $0.284 \pm 0.173$ & $0.105 \pm 0.042$ \\
Ovary & $0.045 \pm 0.008^{\mathrm{a}, \mathrm{b}}$ & $0.051 \pm 0.007^{\mathrm{a}}$ & $0.031 \pm 0.010^{\mathrm{b}}$ \\
Uterus & $0.116 \pm 0.019^{\mathrm{a}}$ & $0.170 \pm 0.028^{\mathrm{b}}$ & $0.108 \pm 0.018^{\mathrm{a}}$ \\
\hline
\end{tabular}

${ }^{1}$ All values are means \pm SD (standard deviation). a. b Values not sharing a superscript letter are significantly different at $p<0.05$.

カラム ; Nova-Pac C18 (waters, $3.9 \times 150 \mathrm{~mm}$ ), カラム温度 $; 40{ }^{\circ} \mathrm{C}$, 移動相 ; $50 \mathrm{mM}$ 酢酸ナトリウム緩 衝液（pH4.8）：メタノール：アセトニトリル $=50$ ： $35: 15(\mathrm{~V} / \mathrm{V} / \mathrm{V})$, 流速 $: 0.65 \mathrm{ml} / \mathrm{min}$

(4) 血清甲状腺ホルモン分析

血清中の甲状腺ホルモン triiodothyronine ( $\left.\mathrm{T}_{3}\right)$, thyroxine $\left(\mathrm{T}_{4}\right)$, thyroid stimulating hormone (TSH) 濃 度の測定は測定会社（株式会社エスアールエル，東京） に依頼した。

(5) 統計処理

データは平均士標準偏差で表した。飼料からのイソフ ラボン投与を因子とし，一元配置の分散分析を行った。 群間での有意差検定にはDuncanの多重比較法を用いた $(p<0.05)$ 。“ 1 匹の母親ラットが出産した仔ラット全体
重量”に関しては，“1 匹の母親ラットが出産した仔ラ ット雌雄合計数”を共変量とし, 共分散分析で差を検定 した $(p<0.05)$ 。“仔ラットの飼料摂取量”と“体重増 加量”，また“AGD”と“体重”の関係を回帰分析によ って調べた。“仔ラットの飼料摂取量”と“体重増加量”,

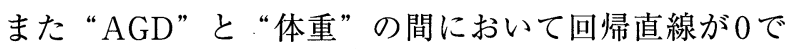
あるか, 回帰の有意性が仮定できなかった場合は分析を 中断し, 群間ごとの比較を一元配置の分散分析により行 った。0でない場合 “体重”を共変量とし，共分散分析 により平均傾斜を比較した。また経時的な体重変化につ いては仔を雌雄に分けHuynh と Feldt（1976）の方法に 従い自由度を調整し, 反復測定分析を行った $(p<0.05)$ 。 統計分析はSPSSパッケージ (SPSS for Windows ver. 11.0）により行った。 
Table 5 Body and organ weights, anogenital distance, and dry weight of the femur in suckling pups of dams fed the control diet or diet containing genistein or daidzein $0.50 \mathrm{~g} / \mathrm{kg}$ during pregnancy and lactation on $\mathrm{PND}^{1} 4^{2}$

\begin{tabular}{lccc}
\hline \multicolumn{1}{c}{ Group } & Control group & Genistein group & Daidzein group \\
\hline $\begin{array}{l}\text { Number of suckling pups } \\
\text { Body weight } \\
\text { of suckling pups (g) }\end{array}$ & 40 & 40 & 40 \\
\hline Male & $10.6 \pm 0.6^{\mathrm{a}}$ & $10.5 \pm 0.9^{\mathrm{a}}$ & $8.2 \pm 0.5^{\mathrm{b}}$ \\
$\quad$ & & & \\
$\quad n$ & 4 & 4 & 4 \\
Anogenital distance ${ }^{3}(\mathrm{~mm})$ & $6.03 \pm 0.46^{\mathrm{a}}$ & $5.38 \pm 0.14^{\mathrm{b}}$ & $4.27 \pm 0.16^{\mathrm{c}}$ \\
Organ weight (g/100g body weight) & & \\
$\quad$ Liver & $3.82 \pm 0.27$ & $3.85 \pm 0.21$ & $3.49 \pm 0.40$ \\
$\quad$ Kidney & $1.16 \pm 0.04$ & $1.12 \pm 0.09$ & $1.20 \pm 0.10$ \\
$\quad$ Spleen & $0.411 \pm 0.048$ & $0.354 \pm 0.087$ & $0.347 \pm 0.067$ \\
$\quad$ Thymus & $0.160 \pm 0.016$ & $0.196 \pm 0.035$ & $0.167 \pm 0.073$ \\
$\quad$ Perirenal fat & $0.112 \pm 0.048^{\mathrm{a}, \mathrm{b}}$ & $0.138 \pm 0.030^{\mathrm{a}}$ & $0.081 \pm 0.013^{\mathrm{b}}$ \\
$\quad$ Testis & $0.224 \pm 0.039$ & $0.193 \pm 0.012$ & $0.239 \pm 0.046$ \\
Dry weight of left femur & $0.068 \pm 0.013$ & $0.059 \pm 0.002$ & $0.057 \pm 0.005$ \\
(g/ $/ 00 \mathrm{~g}$ body weight) & & & \\
\hline
\end{tabular}

Female

$$
n
$$

Anogenital distance (mm)

Liver

Kidney

Spleen

Thymus

Perirenal fat

Uterus

Dry weight of left femur

(g/100g body weight)
4

$3.84 \pm 0.25$

$1.18 \pm 0.06$

$0.352 \pm 0.061$

$0.143 \pm 0.018$

$0.028 \pm 0.017$

$0.037 \pm 0.026$

$0.070 \pm 0.006^{a}$

\section{4}

$2.81 \pm 0.34^{\mathrm{a}}$

$3.76 \pm 0.36$

$1.10 \pm 0.08$

$0.377 \pm 0.111$

$0.163 \pm 0.040$

$0.035 \pm 0.024$

$0.063 \pm 0.015$

$0.060 \pm 0.002^{a, b}$
4

$1.79 \pm 0.07^{\mathrm{b}}$

$3.61 \pm 0.21$

$1.01 \pm 0.14$

$0.284 \pm 0.105$

$0.144 \pm 0.045$

$0.024 \pm 0.011$

$0.048 \pm 0.003$

$0.055 \pm 0.009^{\mathrm{b}}$

${ }^{1}$ The day of birth was designated as PND (postnatal day) 1.

${ }^{2}$ All values are means \pm SD (standard deviation). a, b, c Values not sharing a superscript letter are significantly different at $p<0.05$.

${ }^{3}$ If the parallelism could not be assumed between anogenital distance and body weight, anogenital distance was not done covariance analysis, and it was evaluated by one-way analysis of variance $(p<0.05)$.

\section{結}

\section{果}

\section{1. 出産結果}

出産日前日の母親ラットの体重は D 群が他の 2 群より も低值を示した（Table 2)。一方，1匹の母親ラットが 出産した仔ラットの数では雌雄別, 雌雄合計数とも群間 で差はなかった。しかし，1匹の母親ラットが出産した 仔ラット全体の体重では D 群が低值を示し，1匹の母 親ラットが出産した仔ラット 1 匹の平均体重においても D群で有意に低值を示した。

\section{2. 母親ラットの体重変化}

母親ラットでは妊娠期, 授乳期どちらにおいても C 群, G 群と比較しD群で体重増加が抑制された（Fig. 1)。母
親ラットの妊娠期, 授乳期の飼料摂取量, 妊娠期の飼料 効率においても D 群が他の 2 群よりも低值を示した (Table 3)。授乳期の飼料効率は群間で有意差はなかっ た（デー夕は示していない）。さらに妊娠期および授乳 期における母親ラットの飼料摂取量を，母親ラットの体 重を共変量とし共分散分析で検定（ $p<0.05 ）$ したとこ ろ，群間での有意差は認められなかった。従って，D群 の体重増加抑制は飼料摂取量の低下と飼料効率の低下に よるものである。

出産21日目（離乳日）の母親ラットの肝臓重量は, $\mathrm{D}$ 群が $\mathrm{G}$ 群と比較し高值を示した（Table 4)。また，D 群の卵巣重量は $\mathrm{C}$ 群と比較し低い傾向 $(p=0.053)$ を示 
Table 6 Body and organ weights, anogenital distance, and dry weight of the femur in offspring of dams fed the control diet or diet containing genistein or daidzein $0.50 \mathrm{~g} / \mathrm{kg}$ during pregnancy and lactation on $\mathrm{PND}^{1} 15^{2}$

\begin{tabular}{|c|c|c|c|}
\hline Group & Control group & Genistein group & Daidzein group \\
\hline Number of suckling pups & 32 & 32 & 32 \\
\hline $\begin{array}{l}\text { Body weight } \\
\text { of suckling pups (g) }\end{array}$ & $41.3 \pm 3.3^{\mathrm{a}}$ & $41.8 \pm 1.8^{\mathrm{a}}$ & $33.2 \pm 2.7^{b}$ \\
\hline \multicolumn{4}{|l|}{ Male } \\
\hline$n$ & 4 & 4 & 4 \\
\hline Anogenital distance ${ }^{3}(\mathrm{~mm})$ & $11.0 \pm 1.0^{\mathrm{a}, \mathrm{b}}$ & $11.8 \pm 0.7^{\mathrm{a}}$ & $10.0 \pm 1.0^{\mathrm{b}}$ \\
\hline \multicolumn{4}{|c|}{ Organ weight ( $\mathrm{g} / 100 \mathrm{~g}$ body weight) } \\
\hline Liver & $2.91 \pm 0.04$ & $2.70 \pm 0.13$ & $2.74 \pm 0.15$ \\
\hline Kidney & $1.035 \pm 0.098$ & $0.946 \pm 0.089$ & $0.928 \pm 0.044$ \\
\hline Spleen & $0.352 \pm 0.021$ & $0.348 \pm 0.066$ & $0.356 \pm 0.082$ \\
\hline Thymus & $0.303 \pm 0.214$ & $0.298 \pm 0.055$ & $0.308 \pm 0.042$ \\
\hline Perirenal fat & $0.418 \pm 0.017^{a}$ & $0.452 \pm 0.027^{\mathrm{a}}$ & $0.295 \pm 0.083^{\mathrm{b}}$ \\
\hline Testis & $0.348 \pm 0.024$ & $0.333 \pm 0.022$ & $0.448 \pm 0.115$ \\
\hline $\begin{array}{l}\text { Dry weight of left femur } \\
(\mathrm{g} / 100 \mathrm{~g} \text { body weight })\end{array}$ & $0.098 \pm 0.002^{\mathrm{a}}$ & $0.099 \pm 0.002^{\mathrm{a}, \mathrm{b}}$ & $0.102 \pm 0.004^{b}$ \\
\hline \multicolumn{4}{|l|}{ Female } \\
\hline$n$ & 4 & 4 & 4 \\
\hline Anogenital distance $(\mathrm{mm})$ & $6.90 \pm 0.74^{\mathrm{a}}$ & $7.80 \pm 0.29^{b}$ & $6.22 \pm 0.36^{\mathrm{a}}$ \\
\hline \multicolumn{4}{|c|}{ Organ weight ( $\mathrm{g} / 100 \mathrm{~g}$ body weight) } \\
\hline Liver & $2.90 \pm 0.23$ & $2.91 \pm 0.04$ & $2.75 \pm 0.03$ \\
\hline Kidney & $1.044 \pm 0.063^{\mathrm{a}}$ & $0.994 \pm 0.065^{\mathrm{b}}$ & $0.931 \pm 0.061^{\mathrm{b}}$ \\
\hline Spleen & $0.336 \pm 0.017$ & $0.349 \pm 0.048$ & $0.388 \pm 0.062$ \\
\hline Thymus & $0.308 \pm 0.051$ & $0.350 \pm 0.044$ & $0.327 \pm 0.062$ \\
\hline Perirenal fat & $0.378 \pm 0.077$ & $0.336 \pm 0.043$ & $0.299 \pm 0.096$ \\
\hline Uterus & $0.080 \pm 0.008$ & $0.087 \pm 0.006$ & $0.085 \pm 0.009$ \\
\hline $\begin{array}{l}\text { Dry weight of left femur } \\
(\mathrm{g} / 100 \mathrm{~g} \text { body weight })\end{array}$ & $0.098 \pm 0.003$ & $0.100 \pm 0.005$ & $0.104 \pm 0.004$ \\
\hline
\end{tabular}

${ }^{1}$ The day of birth was designated as PND (postnatal day) 1.

${ }^{2}$ All values are means \pm SD (standard deviation). a. b Values not sharing a superscript letter are significantly different at $p<0.05$.

${ }^{3}$ If the parallelism could not be assumed between anogenital distance and body weight, anogenital distance was not done covariance analysis, and it was evaluated by one-way analysis of variance $(p<0.05)$.

し，G群ではC 群，D群と比較し子宮重量は高值を示し た。

\section{3. 仔ラットの成長}

生後4日目の仔ラットでは, D群は他の群に比べて体 重が低值を示し，AGDが短くなった。また，大腿骨乾 燥重量はD群の雌が低值を示した（Table 5)。

生後 15 日目の仔ラットでも D群の体重が低值を示し, 雄においては後腹壁脂肪相対重量でも低值を示したが, 雌において有意差はなかった（Table 6)。一方，骨乾燥 重量は雄の D 群ではC 群と比較し高值を示した。雄の $\mathrm{AGD}$ は D 群において G 群と比較すると短くなったが, $\mathrm{C}$ 群と比較すると $\mathrm{G}$ 群, D群とも差は認められなかった。
雌の AGDは C 群，D群と比較し G 群で有意に長くなっ た。雌の腎臓重量はC 群と比較し G 群, D 群が低值を示 したが，それ以外の臓器に関して差はみられなかった。

離乳後の仔ラットの体重増加はD群では他の 2 群と比 較し抑制された（Table 5，6）。離乳後（生後21～34日 目）の仔ラットの飼料摂取量は, D群が他の 2 群と比べ 低值を示したが, 飼料効率では群間で差はみられなかっ た (Table 7)。

生後34日目の仔ラットでもC 群, G群と比較し, D群 において体重が低值を示した（Table 8)。雌において脾 臓重量がC 群と比較し D 群で高值を示したが; その他の 臓器重量, 大腿骨乾燥重量では C 群, $\mathrm{G}$ 群, D群の間で 
Table 7 Food intake and food efficiency in pups of dams fed the control diet or diet containing genistein or daidzein $0.50 \mathrm{~g} / \mathrm{kg}$ during pregnancy and lactation after weaning ${ }^{1,2}$

\begin{tabular}{lccc}
\hline \multicolumn{1}{c}{ Group } & $\begin{array}{c}\text { Control group } \\
(n=8)\end{array}$ & $\begin{array}{c}\text { Genistein group } \\
(n=8)\end{array}$ & $\begin{array}{c}\text { Daidzein group } \\
(n=8)\end{array}$ \\
\hline $\begin{array}{l}\text { Food intake }{ }^{3} \text { for 14 days }(\mathrm{g}) \\
\quad \text { Post weaning) }\end{array}$ & $173.3 \pm 4.8^{\mathrm{a}}$ & $171.5 \pm 7.3^{\mathrm{a}}$ & $158.9 \pm 5.3^{\mathrm{b}}$ \\
$\begin{array}{l}\text { Food efficiency } \\
\quad \text { Body weight gain }(\mathrm{g}) / \text { food intake }(\mathrm{g})]\end{array}$ & $0.513 \pm 0.034$ & $0.458 \pm 0.035$ & $0.500 \pm 0.050$ \\
\hline
\end{tabular}

${ }^{1}$ All values are means $\pm \mathrm{SD}$ (standard deviation). $\quad{ }^{\mathrm{a}, \mathrm{b}}$ Values not sharing a superscript letter are significantly different at $p<0.05$.

${ }^{2}$ All pups were fed the control diet after weaning until sacrificed.

${ }^{3}$ If the parallelism could not be assumed between food intake and body weight gain, food intake was not done covariance analysis, and it was evaluated by one-way analysis of variance $(p<0.05)$.

Table 8 Body and organs weights, and dry weight of the femur in pups of dams fed the control diet or diet containing genistein or daidzein $0.50 \mathrm{~g} / \mathrm{kg}$ during pregnancy and lactation on $\mathrm{PND}^{1} 34^{2}$

\begin{tabular}{lccc}
\hline \multicolumn{1}{c}{ Group } & Control group & Genistein group & Daidzein group \\
\hline $\begin{array}{l}\text { Number of weaning rats } \\
\text { Body weight } \\
\text { of weaning rats }(\mathrm{g})\end{array}$ & 8 & 8 & 8 \\
\hline Male & $148.7 \pm 4.8^{\mathrm{a}}$ & $146.1 \pm 5.9^{\mathrm{a}}$ & $133.1 \pm 3.2^{\mathrm{b}}$ \\
$\quad$ & & & \\
$\quad$ & 4 & 4 & 4 \\
Organ weight (g/100g body weight) & $5.00 \pm 0.21$ & $4.73 \pm 0.23$ & $4.66 \pm 0.23$ \\
$\quad$ Liver & $0.978 \pm 0.034$ & $0.963 \pm 0.041$ & $0.935 \pm 0.063$ \\
Kidney & $0.354 \pm 0.099$ & $0.332 \pm 0.033$ & $0.405 \pm 0.036$ \\
$\quad$ Spleen & $0.328 \pm 0.029$ & $0.314 \pm 0.021$ & $0.362 \pm 0.040$ \\
$\quad$ Thymus & $0.649 \pm 0.058$ & $0.590 \pm 0.069$ & $0.636 \pm 0.274$ \\
$\quad \begin{array}{l}\text { Perirenal fat } \\
\text { Testis }\end{array}$ & $0.920 \pm 0.034$ & $0.938 \pm 0.112$ & $0.918 \pm 0.026$ \\
$\begin{array}{l}\text { Dry weight of left femur } \\
\text { (g/100g body weight) }\end{array}$ & $0.142 \pm 0.008$ & $0.153 \pm 0.003$ & $0.150 \pm 0.012$ \\
\hline
\end{tabular}

Female

$n$

4

4

4

Organ weight ( $\mathrm{g} / 100 \mathrm{~g}$ body weight)

$\begin{array}{lccc}\text { Liver } & 4.77 \pm 0.45 & 4.97 \pm 0.24 & 4.72 \pm 0.45 \\ \text { Kidney } & 0.934 \pm 0.075 & 0.955 \pm 0.041 & 0.914 \pm 0.064 \\ \text { Spleen } & 0.330 \pm 0.048^{\mathrm{a}} & 0.325 \pm 0.023^{\mathrm{a}} & 0.401 \pm 0.036^{\mathrm{b}} \\ \text { Thymus } & 0.328 \pm 0.070 & 0.361 \pm 0.057 & 0.351 \pm 0.041 \\ \text { Perirenal fat } & 0.604 \pm 0.071 & 0.520 \pm 0.106 & 0.504 \pm 0.144 \\ \text { Ovary } & 0.045 \pm 0.005 & 0.047 \pm 0.006 & 0.049 \pm 0.029 \\ \text { Uterus } & 0.136 \pm 0.050 & 0.124 \pm 0.011 & 0.129 \pm 0.027 \\ \text { Dry weight of left femur } & & & \\ \text { (g/100g body weight) } & 0.141 \pm 0.007 & 0.143 \pm 0.006 & 0.139 \pm 0.004\end{array}$

${ }^{1}$ The day of birth was designated as PND (postnatal day) 1.

${ }^{2}$ All values are means \pm SD (standard deviation). $\quad{ }^{a}$, b Values not sharing a superscript letter are significantly different at $p<0.05$. 
Table 9 Concentrations of genistein, daidzein and equol in the serum and stomach contents of suckling pups of dams fed the control diet or diet containing genistein or daidzein $0.50 \mathrm{~g} / \mathrm{kg}$ during pregnancy and lactation ${ }^{1}$

\begin{tabular}{|c|c|c|c|}
\hline Group & Control group & Genistein group & Daidzein group \\
\hline \multicolumn{4}{|l|}{$\mathrm{PND}^{2} 4$} \\
\hline$n$ & 8 & 8 & 7 \\
\hline \multicolumn{4}{|l|}{ Serum } \\
\hline Genistein $(\mathrm{nmol} / \mathrm{m} l)$ & N. D. ${ }^{3}$ & N. D. & N. D. \\
\hline Daidzein $(\mathrm{nmol} / \mathrm{m} l)$ & N. D. & N. D. & N. D. \\
\hline Equol $(\mathrm{nmol} / \mathrm{m} l)$ & N. D. & N. D. & $0.069 \pm 0.018$ \\
\hline \multicolumn{4}{|l|}{ Stomach contents } \\
\hline Genistein $(\mathrm{nmol} / \mathrm{g})$ & N. D. & $0.272 \pm 0.017$ & N. D. \\
\hline Daidzein $(\mathrm{nmol} / \mathrm{g})$ & N. D. & N. D. & $1.12 \pm 0.32$ \\
\hline Equol $(\mathrm{nmol} / \mathrm{g})$ & N. D. & N. D. & $1.88 \pm 0.52$ \\
\hline \multicolumn{4}{|l|}{ PND 15} \\
\hline$n$ & 8 & 8 & 7 \\
\hline \multicolumn{4}{|l|}{ Serum } \\
\hline Genistein $(\mathrm{nmol} / \mathrm{ml})$ & N. D. & N. D. & N. D. \\
\hline Daidzein $(\mathrm{nmol} / \mathrm{m} l)$ & N. D. & N. D. & $0.59 \pm 0.02$ \\
\hline Equol $(\mathrm{nmol} / \mathrm{m} l)$ & N. D. & N. D. & $1.28 \pm 0.35$ \\
\hline \multicolumn{4}{|l|}{ Stomach content } \\
\hline Genistein $(\mathrm{nmol} / \mathrm{g})$ & N. D. & $2.04 \pm 2.00$ & N. D. \\
\hline Daidzein $(\mathrm{nmol} / \mathrm{g})$ & N. D. & N. D. & $5.29 \pm 1.34$ \\
\hline Equol $(\mathrm{nmol} / \mathrm{g})$ & N. D. & N. D. & $12.54 \pm 8.81$ \\
\hline
\end{tabular}

${ }^{1}$ All values are means \pm SD (standard deviation).

${ }^{2}$ The day of birth was designated as PND (postnatal day) 1.

${ }^{3}$ Not detected.

差はみられなかった。

4. 仔ラットの血清中および胃内容物中のイソフラボ ン濃度

生後4日目の仔ラットでは，D群の血清中においての みエクオールが検出された（Table 9)。生後4日目の仔 ラット胃内容物中では, D群でダイゼイン, エクオール, $\mathrm{G}$ 群でゲニステインが検出された。生後15日目の仔ラ ットの血清中では, D群に打いてダイゼイン, エクオー ルが検出された。生後15日目の仔ラット胃内容物中で は，G群においてはゲニステインが検出され，D群では ダイゼイン, エクオールが検出された。生後 20 日目の 仔ラット胃内容物中および血清中, 出産後 20 日目の母 親ラットの血清中イソフラボン濃度を測定したが，ゲニ ステイン，ダイゼイン，エクオールのいずれも検出でき なかった（データは示していない）。

5. 母親ラット, 仔ラットの血清甲状腺ホルモン濃度 母親ラットの血清中の $\mathrm{T}_{4}$ 濃度は $\mathrm{G}$ 群において $\mathrm{C}$ 群と 比較し高值を示したが, $\mathrm{T}_{3}, \mathrm{TSH}$ では差がなかった (Table 10)。生後34日目の仔ラットにおいては $\mathrm{T}_{3}, \mathrm{~T}_{4}$, TSHのいずれも G 群, D 群でC 群との間に有意差はみら れなかった。
考察

本実験では妊娠期・授乳期に飼料からゲニステイン， ダイゼインを摂取した母親ラットにおける妊娠への影 響，またその母親ラットから産まれた仔ラットの成長に 及ぼすゲニステインとダイゼインの影響の違いを観察し た。あわせて，母乳のみを摂取している仔ラットの胃内 容物および血清中のゲニステイン, ダイゼインとその代 謝産物であるエクオール濃度を測定した。

飼料を介してダイゼイン投与を行った母親ラットとそ の仔ラットに打いて体重増加が抑制された（Fig. 1, Table 5，6，8)。この結果よりダイゼインとゲニステイ ンでは生体影響が違うことが示された。とくにダイゼイ ン摂取による飼料摂取量の低下が体重抑制の要因となっ ていた。一方，母乳を介してダイゼインを摂取した仔ラ ットの胃内容物および血清中にダイゼインの代謝産物で あるエクオールが検出された。これにより，代謝産物で あるエクオールが母乳を介して母親から乳仔へ移行して いることが観察された。

本実験では飼料 $1 \mathrm{~kg}$ 当たりにゲニステイン，ダイゼイ ンそれぞれ $500 \mathrm{mg}$ を混合し，母親ラットの飼料㠌取を 介して乳仔ラットへゲニステイン，ダイゼインを投与し 
Table 10 Concentrations of triiodothyronine $\left(\mathrm{T}_{3}\right)$, thyroxine $\left(\mathrm{T}_{4}\right)$ and thyroid stimulating hormone (TSH) in the serum of dams fed the control diet or diet containing genistein or daidzein $0.50 \mathrm{~g} / \mathrm{kg}$ during pregnancy and lactation and their suckling pups ${ }^{1}$

\begin{tabular}{|c|c|c|c|}
\hline Group & Control group & Genistein group & Daidzein group \\
\hline \multicolumn{4}{|l|}{ Dam } \\
\hline$n$ & 4 & 4 & 4 \\
\hline $\mathrm{T}_{3}(\mathrm{ng} / \mathrm{m} l)$ & $1.00 \pm 0.00$ & $1.00 \pm 0.08$ & $1.00 \pm 0.08$ \\
\hline $\mathrm{T}_{4} \cdot(\mu \mathrm{g} / \mathrm{m} l)$ & $4.13 \pm 0.30^{\mathrm{a}}$ & $4.90 \pm 0.61^{\mathrm{b}}$ & $4.65 \pm 0.25^{\mathrm{a}, \mathrm{b}}$ \\
\hline TSH $(\mathrm{ng} / \mathrm{m} l)$ & $5.90 \pm 1.81$ & $6.03 \pm 0.85$ & $5.10 \pm 0.94$ \\
\hline \multicolumn{4}{|l|}{ Pups $\mathrm{PND}^{2} 34$} \\
\hline \multicolumn{4}{|l|}{ Male } \\
\hline$n$ & 4 & 4 & 4 \\
\hline $\mathrm{T}_{3}(\mathrm{ng} / \mathrm{m} l)$ & $1.18 \pm 0.05$ & $1.15 \pm 0.06$ & $1.20 \pm 0.00$ \\
\hline $\mathrm{T}_{4}(\mu \mathrm{g} / \mathrm{m} l)$ & $6.03 \pm 1.32$ & $5.05 \pm 0.42$ & $5.53 \pm 0.34$ \\
\hline $\mathrm{TSH}(\mathrm{ng} / \mathrm{m} l)$ & $6.00 \pm 0.38$ & $5.53 \pm 0.83$ & $5.83 \pm 1.52$ \\
\hline \multicolumn{4}{|l|}{ Female } \\
\hline$n$ & 4 & 4 & 4 \\
\hline $\mathrm{T}_{3}(\mathrm{ng} / \mathrm{m} l)$ & $1.20 \pm 0.10$ & $1.23 \pm 0.06$ & $1.23 \pm 0.10$ \\
\hline $\mathrm{T}_{4}(\mu \mathrm{g} / \mathrm{m} l)$ & $5.20 \pm 0.70$ & $5.77 \pm 0.75$ & $6.15 \pm 0.62$ \\
\hline $\mathrm{TSH}(\mathrm{ng} / \mathrm{m} l)$ & $5.90 \pm 0.75$ & $5.70 \pm 1.45$ & $5.10 \pm 1.74$ \\
\hline
\end{tabular}

ているものである。Fritzらの報告では,ゲニステイン $250 \mathrm{mg} / \mathrm{kg}$ を含む飼料を摂取した母親ラットでは, 出産 後 7 日目の血清ゲニステイン濃度は $418 \mathrm{nM}$ であるのに 対し, 仔ラットの胃内容物では $4,439 \mathrm{nM}$, 血清では $726 \mathrm{nM}$ と高濃度であった ${ }^{19) 。 ま た, ~ L a m a r t i n i e r e ~ ら の ~}$ 実験では, ダイゼイン $1,000 \mathrm{mg} / \mathrm{kg}$ を含む飼料を摂取し た母親ラットの血中のダイゼイン，エクオール濃度はそ れぞれダイゼイン $407 \pm 174 \mathrm{nM}$ ，エクオール 4,462 $1,551 \mathrm{nM}$ であった ${ }^{20)}$ 。さらにこの報告では，生後7日目 の仔ラットの血中ダイゼイン，エクオール濃度はそれぞ

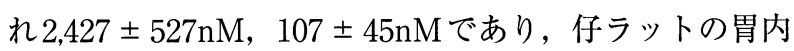
容物中では 7,583 $\pm 2,189 \mathrm{nM}, 1,700 \pm 148 \mathrm{nM}$ であった。 我々の実験において生後15日目の仔ラット血清ゲニス テイン, ダイゼイン, エクオール濃度は D 群でダイゼ イン $592 \pm 17 \mathrm{nM}$ ，エクオール $1,278 \pm 350 \mathrm{nM}$ であった。 ゲニステインが最大血中濃度に達するのはおよそ投与 8 時間後, ダイゼインでは 6 時間後であり, その後, 腸肝 循環を経由し代謝, 排泄される ${ }^{21,22)}$ 。本実験のゲニス テイン，ダイゼイン，エクオール濃度はFritzや Lamartiniere らの報告と比較すると值が低い。これは, 本実験においてはゲニステイン, ダイゼインを生後 13 日目までしか投与していないため, 投与後時間が経過し, 血中濃度が低下していたためと思われる。他方, 仔ラッ
ト胃内容物中のゲニステイン, ダイゼイン, エクオール 濃度は血清イソフラボン濃度のおよそ10倍の高濃度が 検出され, とくにエクオールは高濃度であった。さらに, エストロゲンが脂肪組織の代謝, 蓄積, 分布に関係して いるとの報告がある ${ }^{23)}$ 。本実験の母親ラット，仔ラット どちらにおいても後腹壁脂肪相対重量が $\mathrm{C}$ 群と比較し, D群で低い傾向であった（Table 4，5，6，8）。そこで, 今回, D群において観察された体重増加抑制はダイゼイ ンのみの影響ではなく，エストロゲン様の強い生理活性 をもったエクオールによる影響の可能性も考えられる。 さらに, 臓器重量の結果から体重全体の差は考えにくい。 そのことより, D群では筋肉重量増加が少なかった可能 性も考えられる。

ホルモンレベルを変化させうる食事成分は，母親と子 供の両方にとってホルモン感受性の強い妊娠期間におい てその安全性は重要な問題である。一方で，妊娠動物へ のエストロゲン投与は妊娠に影響を与えることが知られ ている。それらの影響は妊娠時の体重増加量の低下を生 じ，その結果，出生数，一腹の胎児数，出生時体重の低 下を生じることが報告されている ${ }^{8)}$ 。本実験において， ダイゼインを捸取した母親ラットでの体重増加抑制は飼 料摂取量の低下，さらに飼料効率の低下によるものであ った。Delclosらは，妊娠 7 日目の母親ラットにゲニス 
テイン $1,250 \mathrm{ppm}$ の飼料を投与したところ, 出産前の母 親ラットに扔いて体重と飼料摂取量が減少し，さらに母 親ラット 1 匹から生まれてきた仔ラット全体の体重，匹 数が減少したが，625ppmではそれらの影響が生じなか ったことを報告した ${ }^{24)}$ 。我々の実験に用いたゲニステイ ン, ダイゼイン濃度は $500 \mathrm{ppm}$ であり, ゲニステインで はそのような影響は観察されなかった。これは以前我々 が行った実験結果とも一致している。

他方, 仔ラットの AGD, 臟器重量, 大腿骨乾燥重量 において生後 $4,15,34$ 日目にC 群と比較しD群で差が 観察されたが，いずれも一貫した影響ではなかった (Table 5,6，8)。一方，仔ラットの体重に関しては授乳 期間中から離乳後の成長期において, 一貫してD群で C 群, G群と比較し体重増加が抑制されていた。しかし, $\mathrm{D}$ 群の体重増加は他の群とほぼ平行であり数日の遅れを 示すだけである。従って，授乳期間において決定的ある いは不可逆的な障害を生じたわけではない。母親ラット へダイゼイン $1,000 \mathrm{ppm}$ の飼料を投与した場合, 雌の仔 ラットにおいて授乳期から成長後の生後 50 日目まで一 貫して体重増加が抑制されたことをLamartiniere らが 報告しており ${ }^{20)}$ ，我々の結果と一致している。また，ゲ ニステインを生後間もない仔ラットに $12.5 \mathrm{mg} / \mathrm{kg}$ 経口 投与した結果, 思春期後の仔ラットにおいて体重増加が 抑制されたことをNagao らが報告している25)。しかし， 我々の実験においてはゲニステインを投与した母親ラッ トから産まれた仔ラットでは体重増加抑制は観察されな かった。

今回我々の実験において飼料中のゲニステインとダイ ゼインを同濃度で投与したにもかかわらず，母親ラット と仔ラットの両方において異なる影響が観察された。ゲ ニステインとダイゼインの ERに対する親和性はER $\alpha$, ßのいずれにおいてもダイゼインよりもゲニステインが 強く, 特にゲニステインの $\mathrm{ER} \beta$ に対する親和性が強い ことが報告されている ${ }^{3)}$ 。一方，エクオールのERに対 する親和性はゲニステインより強いことが報告されてい る ${ }^{26)}$ 。ゲニステイン，ダイゼインの生体影響の違いは代 謝物の違いも含めた ERへの親和性による可能性が考元 られるが，詳細は不明である。

本実験において, 飼料によるゲニステイン, ダイゼイ ン投与は母親ラットの甲状腺ホルモン $\mathrm{T}_{4}$ 濃度を上昇さ せた（Table 10）。しかし，仔ラットにおいての影響は 観察されなかった。これまで大豆摄取と甲状腺機能低下 との関係が示唆されているが, 甲状腺腫に影響する大豆 成分は明らかになっていない。Kimuraら, Doergeらの 報告によると, 甲状腺腫はエストロゲン活性から独立し ており, ヨウ素不足は大豆の抗甲状腺作用を增加させ, ヨウ素の補給は予防作用があることが示唆されている 27,
28)。一方で, Chang らは500ppmのゲニステイン投与を 20 週間行ったラットに拈いて, ゲニステイン摂取量の 増加に伴いthyroid peroxidase（TPO）活性が用量に依 存して減少しているが, 血清甲状腺ホルモンレベル $\left(\mathrm{T}_{3}, \mathrm{~T}_{4}, \mathrm{TSH}\right)$, 甲状腺重量, 組織病理変化ではゲニ ステイン投与の影響はみられなかったと報告した ${ }^{29}$ 。従 って, TPO活性が大豆イソフラボン摄取に伴って減少 したとしても, 残っている活性は甲状腺機能の恒常性を 維持するのに十分であることを示唆している。本研究の 結果においても大豆イソフラボンの主成分であるゲニス テインやダイゼインはラットの母親や仔の甲状腺ホルモ ンに強い影響を示さなかった。

本実験においての投与量は体重当たりで比較すると日 本人のゲニステイン平均摂取量 ${ }^{30)}$ の 200 倍近い量を摂取 していることになり，そのままヒトに当てはめることは 適切ではない。しかし, Unferらは閉経後女性に1日 $150 \mathrm{mg}$ のイソフラボンを 5 年間摂取させたところ, 子宮 内膜増殖が発生したことを報告している ${ }^{31)}$ 。現在, 大豆 イソフラボンが関与するほとんどの特定保健用食品の 1 日摂取目安量は大豆イソフラボンとして $40 \mathrm{mg}$ である。 しかし, サプリメントの中には1錠に大豆イソフラボン $25 \mathrm{mg}$ を含む商品も販売されており ${ }^{322}$ ，それらを摃取す ることで特定保健用食品の 1 日掑取目安量を越える可能 性がある。大豆イソフラボンを含む特定保健用食品やサ プリメントは主に骨の改善を目的とし, 閉経後の女性が 対象である。他方,「Natural Medicines Comprehensive Database」では妊婦や乳児・幼児はサプリメントからの 摂取はさけ, 食品から大豆イソフラボンを摂取するべき であると記述している33)。我々の研究結果は大豆イソフ ラボンの妊娠期, 授乳期の安全性を考えるためには, さ らにそのメカニズムも含めて詳細に研究する必要性を示 している。今後, 大豆イソフラボンの安全で有効な摂取 量範囲を明らかにすることが求められている。

\section{要 約}

本研究は母親ラットとその母親から産まれた仔ラット に対して，大豆イソフラボンの主成分であるゲニステイ ン，ダイゼイン $(0.50 \mathrm{~g} / \mathrm{kg}$ diet）を含む飼料の投与によ る生体影響の相違を比較検討し, それらの安全性を確認 することを目的として実験を行った。母親ラットではゲ ニステイン，ダイゼイン投与による妊娠，出産に対する 影響を,仔ラットでは成長への影響をそれぞれ観察した。 さらに母乳のみを損取している仔ラットの胃内容物およ び血清中のゲニステイン, ダイゼイン, エクオール濃度 を測定した。

1.母親ラットへの飼料からのダイゼイン投与により母 親ラットの飼料摂取量, 飼料効率が低下し, 体重増加が 
抑制された。さらに 1 匹の母親ラットが出産した仔ラッ 卜全体重量でもD群が低值を示した。ゲニステイン投 与ではダイゼイン投与と同様の影響は観察されず，ゲニ ステインとダイゼインでは生体影響が異なることが示さ れた。

2.母乳を介してダイゼインを摂取した仔ラットで体重 増加が抑制された。仔ラットの臓器重量, AGD, 大腿 骨乾燥重量では授乳期から成長期において一貫した影響 は観察されなかった。

3.母親ラット, 仔ラットへのゲニステイン，ダイゼイ ン投与は甲状腺ホルモン濃度に明らかな影響を示さなか った。

4.母乳を介してダイゼインを摂取した仔ラットの胃内 容物および血清中に，ダイゼインの代謝産物であるエク オールが多量に検出された。これにより，ダイゼインの 作用の一部はエクオールの強い生理作用を含む可能性が 示唆された。

5. ダイゼイン投与により観察された体重増加抑制を除 いて，母親ラット，仔ラットのどちらにおいても特に健 康上の不都合は観察されなかった。

\section{謝辞}

本研究は厚生科学研究費生活安全総合科学研究事業の 助成によって行った。

\section{文献}

1) Setchell, K.D. : Phytoestrogens : the biochemistry, physiology, and implications for human health of soy isoflavones, Am. J. Clin. Nutr., 68, 1333S1346S (1998)

2 ) Casanova, M., You, L., Gaido, K.W., ArchibequeEngle, S., Janszen, D.B. and Heck, H.A. : Developmental effects of dietary phytoestrogens in SpragueDawley rats and interactions of genistein and daidzein with rat estrogen receptors alpha and beta in vitro, Toxicol. Sci., 51, 236-244（1999）

3 ) Kuiper, G.G., Lemmen, J.G., Carlsson, B., Corton, J.C., Safe, S.H., van, P.T., van, B. and Gustafsson, J.A. : Interaction of estrogenic chemicals and phytoestrogens with estrogen receptor beta, Endocrinology, 13, 4252-4263 (1998)

4 ) Magee, P.J. and Rowland, I.R. : Phyto-oestrogens, their mechanism of action : current evidence for a role in breast and prostate cancer, Br. J. Nutr., 91, 513 -531 (2004)

5 ) Arjmandi, B.H., Birnbaum, R., Goyal, N.V., Getlinger, M.J., Juma, S., Alekel, L., Hasler, C.M., Drum,
M.L., Hollis, B.W. and Kukreja, S.C. : Bone-sparing effect of soy protein in ovarian hormone-deficient rat is related to its isoflavone content, Am. J. Clin. Nutr., 68, 1364S-1368S (1998)

6 ) Greendale, G.A., FitzGerald, G., Huang, M.H., Sternfeld, B., Gold, E., Seeman, T., Sherman, S. and Sowers, M. : Dietary soy isoflavones and bone mineral density : results from the study of women's health across the nation, Am. J. Epidemiol., 155, 746-754 (2002)

7 ) Adlercreutz, H., Hamalainen, E., Gorbach, S. and Goldin, B. : Dietary phyto-oestrogens and the menopause in Japan, Lancet, 16, 1233 (1992)

8 ) Zimmerman, S.A., Clevenger, W.R., Brimhall, B.B. and Bradshaw, W.S. : Diethylstilbestrol-induced perinatal lethality in the rat. II. perturbation of parturition, Biol. Reprod., 44, 583-589 (1991)

9 ) Roberts, D., Veeramachaneni, D.N., Schlaff, W.D. and Awoniyi, C.A. : Effects of chronic dietary exposure to genistein, a phytoestrogen, during various stages of development on reproductive hormones and spermatogenesis in rats, Endocrine, 13, 281-286 (2000)

10) Hydovitz, J.D. : Occurrence of goiter in an infant on a soy diet, N. Engl. J. Med., 18, 351-353 (1960)

11) Fort, P., Moses, N., Fasano, M., Goldberg, T. and Lifshitz, F. : Breast and soy-formula feedings in early infancy and the prevalence of autoimmune thyroid disease in children, J. Am. Coll. Nutr., 9, 164-167 (1990)

12) Flynn, K.M., Ferguson, S.A., Delclos, K.B. and Newbold, R.R. : Effects of genistein exposure on sexually dimorphic behaviors in rats, Toxicol. Sci., 55, 311319 (2000)

13) Kang, K.S., Che, J.H. and Lee, Y.S. : Lack of adverse effects in the $\mathrm{F} 1$ offspring maternally exposed to genistein at human intake dose level, Food Chem. Toxicol., 40, 43-51 (2002)

14) Faber, K.A. and Hughes, C.L. Jr. : Doseresponse characteristics of neonatal exposure to genistein on pituitary responsiveness to gonadotropin releasing hormone and volume of the sexually dimorphic nucleus of the preoptic area (SDN-POA) in postpubertal castrated female rats, Reprod. Toxicol., 7, 35-39 (1993)

15) Picherit, C., Coxam, V., Bennetau-Pelissero, C., Kati-Coulibaly, S., Davicco, M.J., Lebecque, P. and Barlet, J.P. : Daidzein is more efficient than genistein in preventing ovariectomy-induced bone loss in rats, 
J. Nutr., 130, 1675-1681 (2000)

16) Setchell, K.D., Brown, N.M. and LydekingOlsen, E. : The clinical importance of the metabolite equol-a clue to the effectiveness of soy and its isoflavones, J. Nutr., 132, 3577-3584 (2002)

17) Reeves, P.G., Nielsen, F.H. and Fahey, G.C. Jr. : AIN-93G purified diets for laboratory rodents : final report of the American Institute of Nutrition ad hoc writing committee on the reformulation of the AIN76A rodent diet, J. Nutr., 123, 1939-1951 (1993)

18) Gamache, P.H. and Acworth, I.N. : Analysis of phytoestrogens and polyphenols in plasma, tissue, and urine using HPLC with coulometric array detection, Proc. Soc. Ex. Biol. Med., 217, 274-280（1998）

19) Fritz, W.A., Coward, L., Wang, J. and Lamartiniere, C.A. : Dietary genistein : perinatal mammary cancer prevention, bioavailability and toxicity testing in the rat, Carcinogenesis, 19, 2151-2158 (1998)

20) Lamartiniere, C.A., Wang, J., Smith-Johnson, M. and Eltoum, I.E. : Daidzein : bioavailability, potential for reproductive toxicity, and breast cancer chemoprevention in female rats, Toxicol. Sci., 65, 228-238 (2002)

21) Doerge, D.R., Twaddle, N.C., Banks, E.P., Jefferson, W.N. and Newbold, R.R. : Pharmacokinetic analysis in serum of genistein administered subcutaneously to neonatal mice, Cancer Lett., 184, 21-27 (2002)

22) Setchell, K.D., Brown, N.M., Desai, P., ZimmerNechemias, L., Wolfe, B.E., Brashear, W.T., Kirschner, A.S., Cassidy, A. and Heubi, J.E. : Bioavailability of pure isoflavones in healthy humans and analysis of commercial soy isoflavone supplements, J. Nutr., 131, 1362S-1375S (2001)

23) Mayes, J.S. and Watson, G.H. : Direct effects of sex steroid hormones on adipose tissues and obesity, Obes. Rev., 5, 197-216 (2004)

24) Delclos, K.B., Bucci, T.J., Lomax, L.G., Latendresse, J.R., Warbritton, A., Weis, C.C. and
Newbold, R.R. : Effects of dietary genistein exposure during development on male and female SD (Sprague -Dawley) rats, Reprod. Toxicol., 15 , 647-663 (2001)

25) Nagao, T., Yoshimura, S., Saito, Y., Nakagomi, M., Usumi, K. and Ono, H. : Reproductive effects in male and female rats of neonatal exposure to genistein, Reprod. Toxicol., 15, 399-411 (2001)

26) Breinholt, V. and Larsen, J.C. : Detection of weak estrogenic flavonoids using a recombinant yeast strain and a modified MCF7 cell proliferation assay, Chem. Res. Toxicol., 11, 622-629 (1998)

27) Kimura, S., Suwa, J., Ito, M. and Sato, H. : Development of malignant goiter by defatted soybean with iodine-free diet in rats, Gan, 67, 763-765 (1976)

28) Doerge, D.R. and Sheehan, D.M. : Goitrogenic and estrogenic activity of soy isoflavones, Environ. Health Perspect., 110, 349-353 (2002)

29) Chang, H.C. and Doerge, D.R. : Dietary genistein inactivates rat thyroid peroxidase in vivo without an apparent hypothyroid effect, Toxicol. Appl. Pharmacol., 168, 244-252 (2000)

30) Somekawa, Y., Chiguchi, M., Ishibashi, T. and Aso, T. : Soy intake related to menopausal symptoms, serum lipid, and bone mineral density in postmenopausal Japanese women, Obstet Gynecol., 97, 109115 (2001)

31) Unfer, V., Casini, M.L., Costabile, L., Mignosa, M., Gerli, S. and Renzo, G.C. : Endometrial effects of long-term treatment with phytoestrogens : a randomized, double-blind, placebo-controlled study, Fertil Steril., 82, 145-148 (2004)

32) Franke, A.A., Hankin, J.H., Yu, M.C., Maskarinec, G., Low, S.H. and Custer, L.J. : Isoflavone levels in soy foods consumed by multiethnic populations in Singapore and Hawaii, J. Agric. Food Chem., 47, 977-986 (1999)

33) Jellin, J.M. : Natural Medicines Comprehensive Database : Soy, Safety, Children, Pregnancy, Lactation (2005) Pharmacist's Letter, Stockton (受付：平成 17 年 6 月 17 日，受理：平成 17 年 12 月 17 日） 